\title{
Lexis
}

Journal in English Lexicology

Book reviews | 2011

\section{Laurel J. BRINTON, The Comment Clause in English.} Syntactic Origins and Pragmatic Development

Cambridge University Press, 2008, 298 pages

\section{Graham Ranger}

\section{OpenEdition}

\section{Journals}

Electronic version

URL: http://journals.openedition.org/lexis/1951

DOI: $10.4000 /$ lexis. 1951

ISSN: 1951-6215

\section{Publisher}

Université Jean Moulin - Lyon 3

\section{Electronic reference}

Graham Ranger, «Laurel J. BRINTon, The Comment Clause in English. Syntactic Origins and Pragmatic Development », Lexis [Online], Book reviews, Online since 11 February 2011, connection on 23 September 2020. URL : http://journals.openedition.org/lexis/1951 ; DOI : https://doi.org/10.4000/ lexis. 1951

This text was automatically generated on 23 September 2020 .

\section{(c) (1) (9)}

Lexis is licensed under a Creative Commons Attribution-NonCommercial-NoDerivatives 4.0 International License. 


\title{
Laurel J. BRINTON, The Comment Clause in English. Syntactic Origins and Pragmatic Development
}

\author{
Cambridge University Press, 2008, 298 pages
}

\author{
Graham Ranger
}

\section{REFERENCES}

\section{Laurel J. Brinton}

The Comment Clause in English. Syntactic Origins and Pragmatic Development. Cambridge

University Press, 2008. ISBN : 9780521886734 , Prix : £55, 298 pages

1 Laurel Brinton's The Comment Clause in English is, as the cover notes tell us, "the first full-length diachronic treatment [...] focusing on comment clauses formed with common verbs of perception and cognition in a variety of syntactic forms". The book runs to some 280 pages, comprising eleven evenly balanced chapters, an extremely complete seventeen-page bibliography and a helpful author and subject index.

2 The book is organized into eleven chapters. Chapter One defines comment clauses relative to other linguistic categories, Chapter Two reviews the semantic and syntactic development of pragmatic markers, criticising the "matrix-clause hypothesis". Chapter Three presents different processes of change relative to pragmatic markers and comment clauses in particular. Chapters 4-10 involve case studies of comment clauses, including examples of each of Quirk et al's three types, i.e. I think (pseudo matrix clause), as you say (adverbial) and what is more (relative). Chapter 11 concludes the study.

3 In the course of the following review I shall run over the material chapter by chapter before making a critical assessment of the work. 


\section{Chapter One: Introduction}

4 The first chapter, which is also the introduction, aims to provide a definition of clausal pragmatic markers or comment clauses. These involve a variety of formal structures, which may all be said to belong to the category of sentence adverbials. Quirk et al (1985) divide sentence adverbials into sentence-modifying disjuncts (e.g. frankly), or sentenceconnecting conjuncts (e.g. moreover). Among the category of disjuncts Quirk et al (1985) further distinguish style disjuncts (truthfully, generally) and content disjuncts (really, wisely). For Quirk et al "comment clauses are both style and content disjuncts" (5 quoted from Quirk et al 1985). They form a heterogeneous syntactic class with at least three distinct types:

- Comment clauses of the I think type. These are unambiguously parenthetical when non initial, but indeterminate between matrix clauses or parentheticals when initial

- Adverbial comment clauses of the as you say type

- Relative comment clauses of the what is more type.

Brinton discusses Peltola's (1982/1983) typology of comment clauses before considering in more detail the category of parentheticals, to which comment clauses belong. These are defined by "lack of syntactic connection with the clause to which they are attached" (7). They provide "second-order reflection, commentary, or evaluation upon the anchor" (8) and consequently display greater positional mobility, lower, marked-off pitch and semantic independence.

6 There is some disagreement about the typological features of parentheticals, one important problem being that of how one should account for the non-integration of parentheticals in host clause. The transformational approach traditionally considers one category of parentheticals as former main clauses according to a derivation taking us roughly from: I think that the world is flat to I think the world is flat and lastly to The world is flat, I think (Ross 1973 refers to this as "slifting"). Another approach prefers to consider parentheticals as syntactically independent. This runs into problems, however, since a parenthetical is typically incomplete, syntactically, and cannot exist independently of its anchor. When parentheticals are in initial position it is not usually possible to determine whether they are parentheticals or matrix clauses, apart from those cases where they are followed by an interrogative, e.g. I mean, can you think of any other situation...? (12). Some linguists have argued that the absence of that alone is sufficient to indicate parenthetical status (Benveniste 1971 and Wierzbicka 2006) (13). But, as Brinton notes, that tends to be deleted for other reasons too, including register, pronominal subjects in the that clause, the choice of verb etc. It has traditionally been supposed that that-deletion (the transformation leading from I think that to I think Ø) is a historical process. However, Brinton tells us, "the history of that-deletion is complex: there appears to be no simple path from that to the zero form" (14) and indeed Aijmer 1997 "believes that zero may have been the unmarked link in speech through OE and ME” (14).

Comment clauses function as pragmatic markers. Although these are, as a general rule, phonologically short, apart from this feature, comment clauses appear to correspond to most of the defining criteria.

8 The introduction concludes with an overview of the book. In each case, Brinton defines semantic-pragmatic functions for the comment clause in Present Day English corpora, 
then goes back to see when these functions arose, tracing their development (19). Her approach is, she claims, essentially qualitative and corpus-based, relying on a vast diachronic corpus including the OED, the Dictionary of Old English Corpus, the quotation bank of the Middle English Dictionary, the Helsinki Corpus, the University of Virginia Electronic Text Center and modern corpora of British, Australian, American, Canadian and New Zealand English.

\section{Chapter Two: Semantic and syntactic development of pragmatic markers}

9 Although there is some potential for agreement as to the semantic development of pragmatic markers, there is relatively little exploration of their syntactic development. Brinton aims to see "whether we find syntactic clines in the development of pragmatic markers comparable to the semantic-pragmatic clines that have been postulated" (24). The semantic development of pragmatic markers is supposed, after Traugott 1991 etc., to follow a path leading "from propositional meaning, to textual meaning, to expressive or interpersonal meaning" (24). This has since been complexified to yield various possible semantic and pragmatic paths:

- truth-conditional $>$ non-truth-conditional

- content > content / procedural > procedural

- non-subjective $>$ subjective $>$ intersubjective

- intrapropositional scope > extrapropositional scope > discourse scope The second path may be exemplified by indeed (Traugott 2003), only and while and, in former periods of English, by anon and soplice. The path of syntactic development often proposed for comment clauses is

- matrix clause > parenthetical disjunct > pragmatic marker

Brinton proposes to reformulate the second of these tendencies as

- referential (propositional) > non-referential (pragmatic, metalinguistic, procedural) (27).

Syntactically, work has often focussed on the development of adverbial markers, such as then, which are seen to follow two paths of syntactic development:

- adverb $>$ conjunction $>$ pragmatic marker or

- clause-internal adverb > sentential adverb > pragmatic marker.

This trajectory Brinton refers to as the "matrix-clause hypothesis". The hypothesis is challenged for a number of different reasons. Firstly, the derived and original forms are not synonymous, so that This is the trouble in schools, you see is not equivalent to You see that this is the trouble in schools (37). Secondly, although negative matrix clauses are fine, these do not develop into comment clauses (I don't think John is a fink but *John is, I don't think, a fink) (37). Brinton goes on to consider the matrix-clause hypothesis in the light of her diachronic corpora, showing that "the historical data do not always confirm the sequence of development postulated by the hypothesis" (38). The adverbial and relative comment clauses noted by Quirk et al do not accommodate the matrix-clause hypothesis, either, and in fact Brinton (1996) has argued for an adverbial source even for I think parentheticals, which she claims to derive from "an adjoined adverbial structure "as/so (< 'which') I think" in Old English" (44-45). Other comment clauses which appear problematical in the matrix-clause hypothesis are nominal relatives of the 
what's more type and first-person subject + verb sequences that originally take nonclausal complements, like expect, which is far more common with to infinitives than with that clauses. Brinton concludes that, although the matrix-clause hypothesis, is "intuitively appealing [...], in actual cases, the chronology of events proves difficult to establish, and there is often a variety of possible complement clauses". Whatever the path, development is nonetheless always unidirectional: "scope within the proposition > scope over the proposition > scope over discourse". (48)

\section{Chapter Three: Processes of Change}

Chapter Three asks "whether grammaticalization [...] is indeed the process that underlies the development of pragmatic markers" (49). Brinton accepts Hopper and Traugott's (2003) definition of grammaticalization as "the change whereby lexical items and constructions come in certain contexts to serve grammatical functions and, once grammaticalized, continue to develop new grammatical functions" (50). She goes on to cite influential theoretical models, including Lehmann's seven "parameters of grammaticalization" and Hopper's five "principles of grammaticalization", together with other factors such as metaphorization, metonymization, pragmatic strengthening and subjectification. The development of pragmatic markers, claims Brinton, corresponds largely to the widely recognized morphosyntactic and semantic changes involved in grammaticalization, citing the example of only, in its development from an adjective, to a focusing adverb, to an adversative and finally a pragmatic marker. A number of studies are quoted in support of this. One important difference, however, is that, whereas grammaticalization typically involves a reduction in scope, in the case of pragmatic markers, this tendency is reversed, as "they come to relate not to smaller linguistic units but normally to larger stretches of discourse" (55). Regarding the specific category of comment clauses, Brinton quotes Thompson and Mulac (1991) who argue that I think and I guess have undergone "decategorialization of the complementtaking noun + verb sequence into a kind of unitary particle" (58). Insofar as pragmatic markers are, in some respects, on the periphery of standard grammatical paradigms, some linguists prefer to consider their development as involving a specific process of pragmaticalization, in which discourse markers develop from lexical elements "without an intermediate stage of grammaticalization" (p. 61 cit Erman and Kotsinas 1993:79). Brinton moves on to compare lexicalization and grammaticalization. The two processes are similar and some studies have in fact preferred to look at the development of pragmatic markers in terms of lexicalization. Brinton however concurs with Traugott in rejecting this approach, considering the development of pragmatic markers as a definite case of grammaticalization. She notes, in support of this, the fact that a grammaticalized item tends to spread into progressively more contexts, whereas there is no reason to expect the same of a lexicalized item. After briefly considering the related processes of idiomatization, and (inter-)subjectification, Brinton concludes this chapter by saying that her own case studies "follow received opinion for the most part, viewing comment clauses as being the result of grammaticalization, in large part because they undergo decategorialization, lose referential meaning, and acquire functional roles" (72). 


\section{Chapter Four, Comment clauses with say}

15 This chapter is the first of seven dedicated to case studies of specific markers. Brinton begins by considering six different pragmatic uses of "(I) say", illustrated with her corpus examples below:

Say1 'suppose, assume': Say there actually were vultures on his tail

Say2 'about, approximately': Keep the reconstructed stuff down to, say, $5 \%$ of the

whole

Say3 'for example, suppose': If we ran out of flour or sugar, say [...].

Say4 'tell me / us': I say, what's that building over there [...].

Say5 a. 'to express surprise, regret, anger [...] or some other mild emotional

response': "Say, that's our City," bubbles Dolores [...].

b. 'to call or evoke the hearer's attention': Say, you pronounce Kenya funny -.

Say6 a. 'to clarify or explain': [...] quasi-scientific notions. I say quasi-scientific

because...

b. 'to express emphasis': Jump, I say, and be done with it. (74-75)

Examples 4,5 and $6 \mathrm{~b}$ are said to function as parenthetical comment clauses, 2 and 3 as parenthetical adverbials, and 1 and $6 \mathrm{a}$ are, syntactically speaking, part of the clause. After briefly comparing uses of say with uses of like and what in Present Day English, Brinton considers the historical development of the different forms, giving examples and dating earliest documented occurrences where possible. In the light of these data, she adduces two diachronic sources for these pragmatic uses of say. Examples Say 1-4 appear to have evolved from second-person imperative forms with clausal complement, while Say 5-6 seem to have evolved according to the matrix-clause hypothesis, that is, from a matrix I say clause. In the case of derivation from secondperson imperatives, there appears to be, "a syntactic reversal of matrix and subordinate clause: the original matrix imperative comes to function as a parenthetical comment clause" (89). The matrix-clause hypothesis adduced for examples 5-6 is problematical, however, in that its proponents claim that reanalysis is a consequence of the frequent use of matrix-clause I say without that. This is unsupported historically, though, since "[o]f the 180 examples of I say in the Middle English period in the OED databank, only $18 \%$ occur with complement clauses; of these $70 \%$ occur with an explicit complementizer that" (90). Whatever the case, the development of different pragmatic uses of say appears to show characteristic signs of grammaticalization, including decategorialization, phonological attribution, desemanticization, (inter-)subjectification and pragmatic strengthening (90). In reference to pragmatic strengthening, Brinton states: "[t]he extended senses of say 1-3 would seem to be invited inferences deriving from the literal meaning of say as a verb of communication, namely 'speak' > 'suppose' > 'for example' > 'about'" (92). I must admit I find this a debatable chain of inference, and in any case one which would definitely require further argumentation to have anything more than intuitive appeal. Brinton also notes that the different uses of say involve varying degrees of reduction in scope and syntactic fixation in addition to some elements of idiomatization.

Brinton then goes on to give some brief consideration to related pragmatic uses of say, including dare say, (as) you say and that is to say. I daresay provides a clear case of grammaticalization, involving fusion, coalescence, desemanticization and decategorialization (96). Brinton takes issue with Fitzmaurice's (2004) proposal to derive (as) you say from you say, favouring the opposite hypothesis, since "parenthetical as you say predates parenthetical you say" (103). Here again I find this debate rather 
unusual: to derive the challenging you say from the consensual as you say, or vice versa, appears quite unnecessary. The two expressions might equally have developed independently. Lastly, Brinton evokes the semi-performative that is to say for which Visser (1969) suggests the influence of a calque from the French c'est-à-dire. She points to a limited number of examples in Late old English, but concedes that French may have had a reinforcing influence. (107)

In her concluding remarks to this chapter, Brinton runs over the functions of pragmatic markers involving say casting doubt on the matrix clause hypothesis, which appears to be insufficiently supported by historical evidence. She concludes that the pragmatic development of say in all its forms illustrates principles of grammaticalization, including decategorialization, desemanticization, subjectification and intersubjectification. Characteristically, for pragmatic markers, they also expand in scope, from scope over the complement to scope over the discourse.

\section{Chapter Five: I mean}

Brinton begins this chapter by pointing out that clause-initial I mean + declarative clause may be analysed either as a matrix clause or as a parenthetical, and gives the example I mean he was only a member because of my husband (111). Schiffrin (1987) suggests that pragmatic uses of I mean have developed from the literal meaning of intention. Brinton aims in this chapter to test Schiffrin's hypothesis. In Present Day English, I mean is a high-frequency pragmatic marker. Although, among pragmatic markers, I mean has been widely studied, there appears to be no clear consensus as to how it functions. Brinton distinguishes one "full" meaning and four pragmatic meanings as follows:

Full mean: I didn't mean to be rude last Wednesday.

Appositional mean: "I'll see you in the morning." She laughed, "I mean, afternoon."

Causal mean ("I'm saying this because"): "Don't you think it's time you put that thing away? I mean, look at at, it's antique, you could hurt yourself with it."

Expressions of speaker attitude: But Cousin Alexander is rich! Really rich, I mean.

Interpersonal mean: It is because she isn't that she is successful... if you understand what I mean.

The pragmatic meanings are additionally subdivided into various shades of meaning. Brinton uses these functions to guide her in her diachronic study of I mean, which she begins in the Middle English period, the marker being insufficiently represented in the Old English corpus. "Full meanings" are frequent in Middle English. Appositional mean used in reformulation or for explicitness are found in Middle English but, in the "selfrepair or mistake-editing sense", mean only occurs from Early Modern English, e.g. The chiefe use, I meane abuse, of Oaths, is as afore I have said in our Courts of Justice (121). When used to express speaker attitude or interpersonally, mean is found in Middle English but the metacommunicative "causal mean" does not appear before the Modern English period.

Brinton considers two possible paths of syntactic development, either from a matrix clause I mean (that) S or from an adverbial / relative structure \{as / so / which $\}$ I mean. The first possibility appears unlikely, however, given that mean followed by a thatcomplement is rare in any period of English, being more usually followed by a phrasal 
complement. Brinton also rejects the adverbial / relative derivation. Her suggestion is: "At first, I mean governs a phrasal element ( $\{\mathrm{NP}, \mathrm{VP}, \mathrm{AP}, \mathrm{PP}, \mathrm{AdvP}\}$ ) and has scope within the sentence. The bonds between I mean and the phrasal element are weakened or loosened, and I mean can begin to be postposed to the phrasal element. The phrasal element is then reanalyzed as an independent element, and I mean as a syntactically free parenthetical with scope over the sentence" and later over discourse (127).

Semantically, the development of mean is seen to be less linear than Schiffrin's 1987 suggestion would have it. The "extended meanings" of mean can be derived in Gricean fashion "as invited inferences arising in appositional structures, where a previous element in the discourse is restated or reformulated. By the Gricean Maxim of Manner "be brief [avoid unnecessary prolixity]" [...] hearers will make the inference that the same information is not simply being restated but that some additional information is being presented." (129)

Brinton remarks, finally, that I mean exhibits a good many of the characteristics associated with processes of grammaticalization, including decategorialization, desemanticization, some degree of fusion and phonetic attrition, (inter-) subjectification and idiomaticization. Like other pragmatic markers I mean acquires increased scope and syntactic mobility.

\section{Chapter Six: Comment clauses with see}

Brinton's sixth chapter is devoted to comment clauses involving see, specifically (as / so) you see, and see alone. She begins, as previously, by studying the functions of see comment clauses in Present Day English. You see, which is more frequent in British English than American, is generally sentence-final and typically expresses "an explanation or justification for the preceding utterance" (134). As / so you see is far less frequent than you see. Brinton's discussion of its use is brief, considering mainly as you see as presupposing the truth of the matrix, in opposition with you see, seen as truthneutral. So you see is mentioned only briefly, with several illustrative examples, glossed as you may conclude. See, which is again less frequent than you see, is also mentioned, with a number of corpus examples, along with a rather bewildering diversity of postulated meanings. The Old English corpus yields examples of you see, about $10 \%$ of which have that-complements, though the literal meaning of visual perception appears to be far more common than the cognitive sense of understanding, according to Brinton. There are apparently no instances of as you see or of parenthetical you see. The frequency of clausal complements for you see increases in Middle English, as you see makes its appearance, and both you see and as you see acquire cognitive readings and begin to function parenthetically, as in the following examples:

Parenthetical as you see: Of hys presens we were ryth glad; But, as pou seste, he hath forsakyn us sone 1450 (145).

Parenthetical you see: "Schir", said the fox, "it is lenterne, ye see, I can not fische" c1470 (145).

In Early Modern English, the frequency of parenthetical you see increases slightly, while the frequency of you see followed by a that-complement decreases.

Brinton next moves on to consider the history of parenthetical see which begins to function as a pragmatic marker in the 19th century. There exist different hypotheses as to the development of pragmatic see. It may be thought to derive from you see, from do 
you see? or from the imperative see, while Fitzmaurice (2004), suggests a diachronic movement from "subjective" I see to "intersubjective" you see and finally to "interactive" see. Brinton rejects this last hypothesis, considering that the data do not support a relation between first and second person uses, each of which may well have evolved independently, rightly judging that "it could be said that I see functions not in parallel to, but in contrast to you see" (155). The low frequency of complement clauses with or without that in Early Modern English similarly leads her to reject a derivation from you see (that). In fact, Brinton proposes to derive, on the one hand, you see from as you see, and, on the other, see from both the imperative see + clause and the interrogative do you see? while admitting that the first derivational proposition poses problems given the differing pragmatic functions of as you see and you see in Present Day English. These hypotheses are presented clearly, in diagram form. Brinton briefly considers data on parallel forms in Swedish, before concluding, as in previous chapters, by assessing the correspondence between the developments she proposes and characteristic features of grammaticalization. As with the other markers studied, the evolution of pragmatic see is seen to involve decategorialization, desemanticization (metaphorization), and (inter-) subjectification, moving as it does from referential to non-referential meanings.

\section{Chapter Seven: If you will and as it were}

Chapter Seven looks at a pair of semantically related markers which both derive from adverbial clauses. In Present Day English both expressions serve as hedges, "making overt reference to the linguistic means of expression" (163). If you will is often used with metaphors and figures of speech, as if to excuse a particular choice of words. Brinton quotes Shapiro and Shapiro (1993) who, from a prescriptivist stance, disapprovingly see the use of if you will "as the speakers' abnegating responsibility for their own language" (163). Interestingly, Brinton's corpora show the expression to be more fully grammaticalized in Canadian English than in British English. As it were, on the other hand, is equally represented in both varieties and, from the examples Brinton provides, is found in very similar contexts to if you will. Historically, parenthetical if you will is already present in Old English, with the meaning of if you are willing, only acquiring its pragmatic sense in the early modern period. Brinton cites a number of 16th and 17th century examples which disqualify Shapiro and Shapiro's criticism of if you will as a linguistic novelty. As it were is present in Old English in the form swa hit woere, emerging in Middle English both with the conditional meaning as if it were (which will soon disappear) and as a pragmatic parenthetical, in similar contexts to Present Day English. Some linguists appear to have linked the rise of as it were to calques from French or Latin, but Brinton finds no clear evidence for this. The development of the pragmatic meaning of if you will, she suggests, might have originated with examples like the following, where both the gloss as if you are willing to do so and as if you are willing to say so are possible: Call them, if you will, Popish fooles, and addlehead (178). As it were appears to have developed syntactically, Brinton suggests, through a process of reanalysis whereby the complement of were is reanalyzed as an appositive. Hence in the following example, we can either consider pricke as the complement of the conditional as it were, or as appositive to pipe: The gnatte... hap in his moup a pipe, as hit were a pricke, "[o]nce this reanalysis occurs, as hit were becomes syntactically independent (parenthetical) and is free to move" (180). In her conclusion to this short chapter, Brinton considers both if 
you will and as it were to be exemplary illustrations of grammaticalization, involving as they do fixing, fusion, desanticization, decategorialization [and the] acquisition of pragmatic / politeness functions" (183). As it were is deemed to have reached a more fully grammaticalized state than if you will.

\section{Chapter Eight: Comment Clauses with look}

In Chapter Eight, Brinton turns her attention to a variety of comment clauses involving the verb look, including look, as in Look [...] can I tell you something (184) but also lookee, look here and lookit. Look-forms all serve as attention-getters, which may, but generally do not, carry the literal meaning of visual perception. Morphosyntactically, she considers the origins of look-forms as generally unproblematic, (now) look (here) being the imperative, lookee etc. coming from look ye / thee, and lookyhere or lookahere coming from look ye here. The sources of the dialectal American form lookit are less clear and are considered in detail at the end of the chapter. A purely historical section looks at the first occurrences of each form with pragmatic function, and the findings are presented synoptically in table form. Diachronically, one appears to move from [Look] [\{that, whether, how, etc.\} you hear me] to [Look][you hear me] and finally to [Look you][hear me], i.e. the complement clause is reanalyzed as a matrix, its second-person subject joining the imperative, reanalyzed as a parenthetical disjunct. Look you is variously univerbated to form Lookee etc., while look appears last of all, in Late Modern English, with the disappearance of the subject pronoun. The form lookit, which appears mainly in early 20th century North American texts, and appears to carry elements of exasperation or urgency, has followed a different course. This form, illustrated by Lookit. Can't you come back and stay with me? (195), has been considered to derive from look at it (Schourup 2004). Brinton, however, argues that pragmatic lookit finds its source in look to it or look to't which are widely attested in Early and Late Modern English with an apparently similar function. She notes that lookit also exists in a perceptual sense, in which case it derives rather from look at, as in "Lookit this idiot" (199). After a brief consideration of the other sensory verbs hark, listen and hear, Brinton concludes this chapter, as before, by considering whether the development of look-forms matches the criteria for grammaticalization. She concludes that it does, involving processes that include decategorialization, fusion, coalescence, desemanticization, pragmatic strengthening and subjectification. In common with the grammaticalization of other pragmatic markers, but uncharacteristically, as far as grammaticalization in general is concerned, look-forms acquire increased scope and, to some extent, mobility, although they are normally placed clause-initially.

\section{Chapter Nine: What's more and what else}

The two markers studied in Chapter Nine correspond to Quirk's third class of comment clause - that of nominal relatives. What's more, firstly, is described in Present Day English as "expressing expansion, addition or elaboration" (205). Historically, Brinton's examples date from the end of the 16th century, and are, at first, mainly clauseinternal, as what's more takes an element inside the clause as its scope, becoming predominantly clause-external by the 19th century. A rival form, Which is more, with similar function is attested in the 17th century but is absent from modern texts (Mad as 
May-butter, / And which is more, mad for a wench 208). The preterite what was more develops later, essentially in indirect speech. Brinton rejects explanations which might adduce an elided adjective, i.e. What's more + adjective, proposing a development from an adjectival relative, "adjoined to a phrasal category, NP, AP, PP, or VP" (210), to a nominal relative with sentential scope which goes on finally to acquire interpersonal features characteristic of pragmatic markers and comment clauses in particular. What else is used in Present Day English as a pragmatic marker in two ways, either "as a means for the speaker to claim continuation of a turn" (212) or as a means to "call [...] on the hearer to agree [...] with the speaker's beliefs concerning the expectedness of the action described" (214). These two pragmatic functions might be illustrated respectively by the following examples:

Continuative use: "Lucky Harriet," said Mark. "What else? Ah yes; a Secretary at the Ministry of Industry wants you to ring him." (214)

Expectedness use: Of course, on Monday nights they settle down to watch - what else - "Murphy Brown" (213).

31 The first is said to be speaker-oriented, in that the speaker appears to be addressing himself, while the second is hearer-oriented. The pragmatic uses of what else are considered to derive, perhaps unsurprisingly, from elliptical interrogatives. Both what's more and what else exhibit many of the features associated with grammaticalization, including decategorialization, and the acquisition of (inter-)subjective meanings. Typically for comment clauses, the scope of these elements increases as they become grammaticalized.

\section{Chapter Ten: Epistemic / evidential parentheticals - I gather and I find}

The last of Brinton's case studies focuses on the parentheticals I gather and I find. The chapter opens with a review of work on epistemic parentheticals before looking at the two cases in point. Epistemic / evidential parentheticals may be illustrated by I know / believe / guess / suppose etc. each of which functions to "guid[e] the hearer to a proper appreciation of the statement in its context, social, logical or evidential" (220 quoted from Urmson 1952). In the following discussion, Brinton draws attention to a recent approach by Wierzbicka (2006) who "argues that epistemic parentheticals have a relatively late origin in the history of the language, namely, the first half of the eighteenth century [... attributing] their rise to 'culture-specific historical explanations"' (223 quoted from Wierzbicka 2006) and more precisely to the publication of Locke's Essay Concerning Human Understanding. Brinton disagrees with this, citing a previous article in which she had detailed the existence of parentheticals such as I leve / gesse / trowe / suppose / thynke / undertake / wene / woot etc. in Middle English. She then turns to I gather, which is characteristic of spoken English, and the function of which is to express uncertainty, possibly serving "purposes of negative politeness in that the speaker does not wish to impose his or her opinions on the hearer" (227). The verb gather already functions cognitively in Middle English, but only becomes recognizably parenthetical in late 19th century English. As I gather is attested from the late 16th century on, Brinton sees little justification for deriving parenthetical I gather from the adverbial clause, considering the matrix clause hypothesis (i.e. from I gather that $S$ to I gather $\emptyset S$ to $S$, I gather) a likely derivation here. I find is classified by 
Hooper (1975) as a "'semifactive' [denoting] a process of knowing" (230). While the sequence I find is relatively frequent with nominal complements, it is far less frequent than I gather, even, when used as a parenthetical. Parenthetical I find qualifies a statement with "an element of personal experience and of personal opinion derived from personal experience" (233). Historically, find is already used with cognitive meaning in Middle English, and is indeed also used parenthetically, in as I fynde or less frequently as I fynde. The relative low frequency of that-less I find constructions in Present Day English, and a postulated difference in meaning between parenthetical I find and matrix clause I find $S$ lead Brinton to reject the matrix-clause hypothesis in the development of I find in favour of a derivation from as I find to I find, with the ellipsis of as. Both I gather and I find are shown to illustrate processes of grammaticalization, including, as before, decategorialization, fusion, desemanticization and a move from referential to pragmatic, (inter-)subjective meaning.

\section{Chapter Eleven: Concluding remarks}

The final chapter to The Comment Clause in English begins with a review of the theoretical background before synthesizing the results of the case studies with regard to the syntactic development of comment clauses and lastly proposing directions for further related research. The study of comment clauses inevitably runs into the problem of their syntactic status. They can be viewed either as former matrix clauses which, as the syntactic bond between matrix and complement clauses has weakened, have been reanalyzed as parentheticals, or as syntactically independent elements which can be inserted into an anchor clause. For a number of syntactic and semantic reasons, comment clauses can be described as parenthetical pragmatic markers. Brinton has attempted to show that the development of comment clauses is a process of grammaticalization, rather than lexicalization, as other linguists have claimed (Walderheit 2002; 2006). The two processes share a number of properties, but typically "[g]rammaticalization leads to abstract meanings, such as the metalinguistic, metatextual, or epistemic/evidential meanings of the verbs in comment clauses, while lexicalization leads to semantic non-compositionality and [...] specialization rather than generalization of meaning" (243). Another major difference between the two is decategorialization. A lexicalized term may move to a new category, but comment clauses tend to shift from a fully formed clause to an invariable particle. Furthermore, it is possible to establish cross-linguistic parallels in the grammaticalization of related comment clauses while the phenomenon of lexicalization is typically language-specific. The matrix clause hypothesis for syntactic derivation of comment clauses does not, in the light of Brinton's study, appear to be borne out by the diachronic data. In particular, she shows that "the that-clause complement - the postulated source construction - is a minority form in earlier stages of the language, that that-deletion does not increase over time [and] that wh-interrogative or imperative complements as well as phrasal complements may be more frequent than that-complements" (247). Additionally, the matrix-clause hypothesis is unable to account for finite comment clauses of the adverbial type (as it were) or the nominal type (what is more). In the light of such shortcomings it might appear wise to consider comment clauses as syntactically independent elements, but in this case it is difficult to account for their frequent syntactic incompleteness ( $I$ think, for example, requires a priori some sort of complementation). All in all, Brinton concludes that "[t]he results of the case studies in 
this work suggest that the diachronic sources of comment clauses are more varied than previously assumed and that the syntactic developments are considerably more complex and less clear historically than might be expected from a straightforward extension of the matrix clause hypothesis" (249). Among other sources of comment clauses, she suggests "declarative matrix clauses with phrasal complements, imperative matrix clauses [...], adjunct adverbial and / or relative clauses, nominal relative clauses, and interrogative tags" (253). In her directions for further research, Brinton points to Construction Grammar as a fertile theoretical frame within which to study comment clauses. She sketches out a possibly constructional approach to the development of epistemic parenthetical comment clauses of the I think variety which, "[i]nstead of focusing on the development of individual comment clauses in isolation [...] allows [...] the capturing of generalizations across a set of forms which display similar properties, and which have developed in a particular set of ways over time". She concludes that, insofar as Construction Grammar is a multi-tiered approach integrating different types of linguistic features, it appears a rich and promising model for future work in this area.

\section{Critical Assessment} "approximately" is asserted with insufficient argument. The derivation of a pseudomatrix clause like you see from an adverbial clause like as you see also seems questionable. This type of derivation is suggested for a number of markers and, as such, it seems to ignore the role that the conjunction AS plays in the construction of meaning. I would have welcomed a fuller study of markers in their specific context and, indeed, a clearer distinction between the contribution made by the marker and that made by the context in the construction of meaning. Brinton has a tendency to take contextual meanings for core meanings. This leads her to affirm, confusingly, that I daresay is used epistemically to express "speaker tentativeness, with overlays of intersubjective emotions such as dismissiveness or impatience" (109), or that you say serves both "to confirm understanding or to introduce disagreement" (109).

These are minor quibbles, however, in the face of the book's many strengths. Brinton's criticism of the matrix-clause hypothesis is well-argued and convincing. Her skill in organizing such a huge amount of historical material is impressive as is her intellectual honesty in presenting the data, in all their complexity and confusion, without ever seeking to transform them in the interest of her arguments. The data are, incidentally, often remarkable and I found it refreshing to see how some discourse markers or 
modes of expression, which prescriptivist approaches condemn as endemic of declining standards in Present Day English, were already alive and kicking in former states of the language! All in all, The Comment Clause in English is an exemplary piece of scholarship which will be of real interest to researchers working in pragmatics, historical linguistics and grammaticalization theory.

\section{BIBLIOGRAPHY}

AIJMER K., "I think - an English modal particle", in Toril SWAN \& Olaf JANSEN Westvik eds., Modality in Germanic Languages: Historical and Comparative Perspectives, Berlin and New York, Mouton de Gruyter, 1997: 1-47.

BENVENISTE Emile, “Subjectivity in language”, in MEEK Mary Elizabeth (trans.), Problems in General Linguistics, 'Miami Linguistics Series 8', Coral Gables, FL, University of Miami Press, 1971 [1958]: 223-230.

BRINTON Laurel, Pragmatic Markers in English: Grammaticalization and Discourse Functions, 'Topics in English Linguistics 19', Berlin and New York, Mouton de Gruyter, 1996.

ERMAN,B. \& KOTSINAS U.-B., "Pragmaticalization: the case of ba' and you know". Studier i modern språkvetenskap 10, (Acta Universitatis Stockholmiensis, Stockholm Studies in Modern Philology, New Series 10.) Stockholm, Almqvist and Wiksell, 1993: 76-93.

FISCHER Olga ROSENBACH A. \& STEIN Dieter (eds.), Pathways of Change: Grammaticalization in English, 'Studies in Language Companion Series 53', University of Amsterdam / Heinrich Heine Universität Düsseldorf, 2000.

HOOPER Joan B., “On assertive predicates”, in KIMBALL John P. (ed.): Syntax and semantics, Vol. 4, New York / San Francisco / London, Academic Press, (1975), 1975: 91-124.

HOPPER Paul. J., “On Some Principles of Grammaticization”, In: E. TRAUGOTT and B. HEINE (eds), Approaches to Grammaticalization, Volume I: Focus on Theoretical and Methodological Issues, Amsterdam/ Philadelphia, John Benjamins, 2000: 17-35.

HOPPER Paul J. \& TRAUGOTT Elizabeth Closs, Grammaticalization, Cambridge, England, Cambridge University Press, 1993 (2003).

LEHMANN, Christian, "New Reflections on Grammaticalization and Lexicalization", In WISCHER, Ilse; DIEWALD, Gabriele (ed.), New Reflections on Grammaticalization, Amsterdam, Benjamins, 2002: 1-18.

PELTOLA N., “Comment clauses in present-day English”, in KOSKENNIEMI Inna, PENNANEN Esko \& AATONEN Hilkka (eds.), Studies in Classical and Modern Philology, Helsinki, Suomalainen Tidedeakatemia, 1982 (1983): 101-113.

QUIRK Randolph, GREENBAUM S., LEECH G. \& SVARTVIK J., A Comprehensive Grammar of the English Language, London, Longman, 1985.

ROSS John R., "Slifting”, in GROSS Maurice \& SCHÜTZENBERGER Marcel (eds.), The Formal Analysis of Natural Languages, Mouton and Company's Gravenhage, Holland, 1973: 133-172. 
SCHIFFRIN D., Discourse Markers, Cambridge, Cambridge University Press, 1987.

SCHOURUP L., "Lookit and the history of look-forms", in TARO Kagyama \& KISHIMOTO Kideki (eds.), Nihongo no Bunsiki to Gengo Ruikei: Shibatani Masayoshi Kyoju Kanredki-nen Robunshu (The Analysis of Japanese and Linguistic Typology: Festschrift for Professor Masayoshi Shibatani on the Occasion of his Sixtieth Birthday), Tokyo, Kuroshio Press, 2004: 543-558.

SHAPIRO Marianne \& SHAPIRO Michael, “Wimp English”, in American Speech 68, 1993: 327-330.

SWEETSER E.E., From Etymology to Pragmatics: Metaphorical and Cultural Aspects of Semantic Structure, Cambridge, Cambridge University Press, 1990.

THOMPSON Sandra A. \& MULAC Anthony, “A quantitative perspective on the grammaticalization of epistemic parentheticals in English", in TRAUGOTT E. C. \& HEINE B. (eds.), Approaches to grammaticalization, Amsterdam, Benjamins, 1991: 313-339.

URMSON J., "Parenthetical verbs", Mind, 61, 1952: 480-496.

VISSER F. Th., An Historical Syntax of the English Language, Part Three: First Half: Syntactical Units with Two Verbs, Leiden, E.J. Brill, 1969.

WALTERHEIT R., "The rise of discourse markers in Italian: A specific type of language change.”, in FISCHER (ed.), 2006: 61-76.

\section{AUTHORS}

\section{GRAHAM RANGER}

Graham Ranger, Department of English, Université d'Avignon et des Pays de Vaucluse, France. Graham Ranger works as a senior lecturer at the Université d'Avignon et des Pays de Vaucluse where he teaches English Linguistics and Translation. 